\title{
MICROPALEONTOLOGY AND BIOSTRATIGRAPHY EFFICIENT TOOLS IN ARCHAEOLOGICAL RESEARCH. RAW MATERIAL PROVENANCE IN THE UPPER PALAEOLITHIC KASTRITSA CAVE, IOANNINA REGION (GREECE)
}

\author{
Zambetakis-Lekkas A. ${ }^{1}$, and Elefanti P. ${ }^{2}$ \\ ${ }^{1}$ National and Kapodistrian University of Athens, Faculty of Geology and Geoenvironment, \\ Department of Hist. Geology - Paleontology, zambetaki@geol.uoa.gr, \\ ${ }^{2}$ Department of Geography, Royal Holloway, Egham, Surrey, TW 20 E0X United Kingdom \\ Paraskevi.elefanti@rhul.ac.uk
}

\begin{abstract}
The present paper discusses the contribution of Micropaleontology and Biostratigraphy to the archaeological research using as a case study the Upper Palaeolithic cave of Kastritsa in the Ioannina basin, north-west Greece. Thin section analysis applied to a selected number of stone tools from the site suggested that raw materials employed in their manufacture could originate from the loannina basin or even from outcrops in the proximity of the cave. This suggest that once Palaeolithic groups arrived at the cave, they practised low mobility which in turn suggests that a range of subsistence opportunities were available in the area allowing to its inhabitants extensive stays. This hypothesis is well supported by the archaeological record of the site. Micropaleontology and Biostratigraphy can be a useful method in the investigation of raw material provenance, especially when sedimentary rocks are studied, and it can provide significant insights into huntergatherer mobility strategies.
\end{abstract}

Key words: Micropaleontology, Biostratigraphy, raw material, Palaeolithic stone tools.

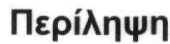

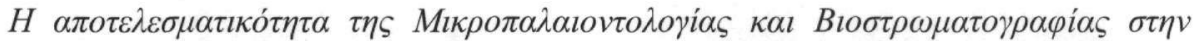

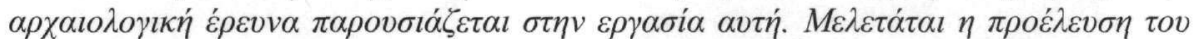

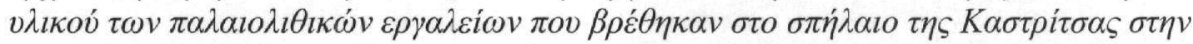

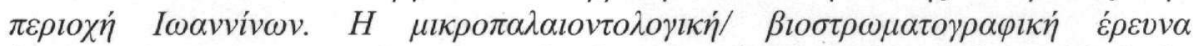

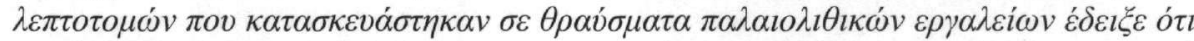

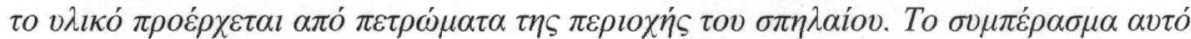

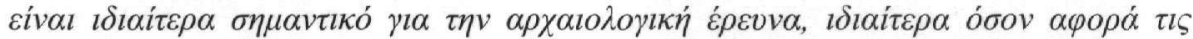

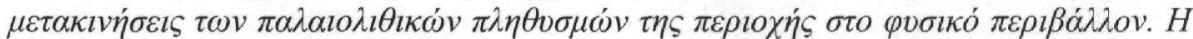

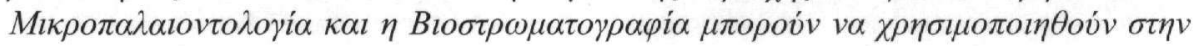




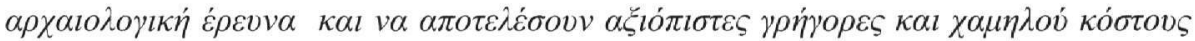

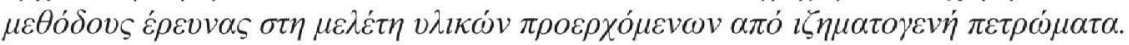

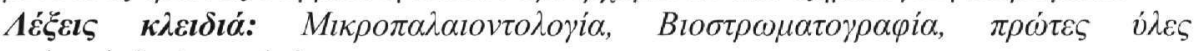

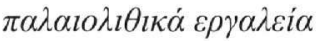

\section{Introduction}

Mobility is a survival strategy which allows humans to better structure their use of the landscape by positioning themselves close to important resources such as water, food and stone. Defining the scale of these systems, while difficult, may be achieved by examining the transport of stone, where transport from source to discard site provides a proxy measure for human movement. This paper summarises the results of the biostratigraphic method applied on a selective number of chipped stone artefacts as part of a larger project whose aim was to undertake original research into the scale and territorial organisation of hunter-gatherer mobility in Greece. The project takes as a case study the site of Kastritsa, a late Upper Palaeolithic cave located on the shores of lake Pamvotis, within the Ioannina basin in eastern Epirus, northwestern Greece. The cave was inhabited between 26,000 and 10,000 years ago and was acted as a focal point in the landscape.

To this end, the excavated collection from the site was investigated and geological survey in the Ioannina basin undertaken. Both the archaeological and geologically sampled material was studied macroscopically (defining basic rock characteristics such as size, colour and cortex) and microscopically through the use of the biostratigraphic method. The project was undertaken by Dr. Paraskevi Elefanti during 2004-2005 and was funded by the Wiener Laboratory of the American School of Classical Studies at Athens.

\section{The biostratigraphic analysis}

Sourcing rock provenance on the basis of petrographic or geochemical traits as well as microfossil evidence has been widely used in archaeology over the past decades (Church 1994, Henderson 2000). For the purpose of this research we opted for the use of the biostratigraphic method which is a low cost, broadly accurate and simple way of estimating the age of geological formations based on the morphology of microfossils in particular of protozoa such as foraminifera and radiolaria. The method has been applied in the past by one of the authors (Zambetakis-Lekkas et al. 2001) as part of a research aiming at identifying geological formations which could provide building material as that used in the construction of the Delphi Oracle ancient monuments. The research has successfully demonstrated the potential of this method with regard to the above issue, a result of particular importance in the conservation of ancient monuments and quarries.

Biostratigraphy is a method based on the evolution of fossils that is a one way and not reversible evolution during the geologic time. Moreover, fossils reflect the depositional paleoenvironment of the geological formations; therefore, the biostratigraphical study of a geological formation determines with precision the time and the paleoenvironment of its deposition, giving the "identity" of the geological formation. Microfossils are encountered in abundance and significant morphological variability within sediments. Therefore, even a small sized rock sample is sufficient for the biostratigraphical analysis. This can be proved very useful in the archaeological research where destructive methods on ancient stone artefacts are usually avoided. Microfossils are identified by the morphology of entire tests extracted by chemical methods usually from unlithified sediments (e.g. marls). This method is also used for the extraction of entire fossils from hard rocks (e.g. radiolarians from carbonates and cherts, conodonts from carbonates). In this case, relative greater quantities of rocks are required. Microfossils included in hard rocks are usually identified by properly oriented thin sections, a method which requires a small amount of sample (i.e. $2 \times 3 \times 1 \mathrm{~cm}$ ). 


\section{Geographic and geological setting}

Kastritsa cave (Fig. 1a) is situated in the western flank of the homonymous hill, southeast of the modern city of Ioannina (Fig. 2). Excavations at the site yielded a large lithic collection made exclusively on chert (Fig. 1b) (Elefanti 2003).
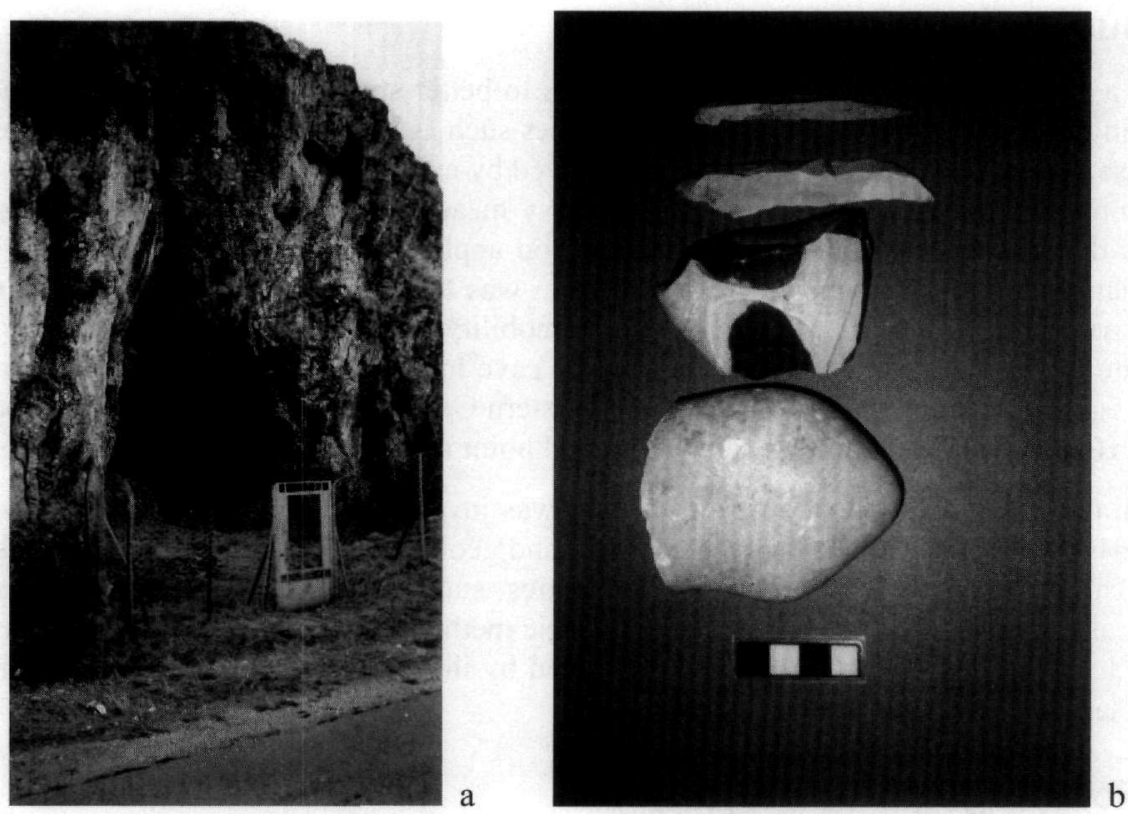

Figure 1 - Cave of Kastritsa (a) and Paleolithic tools (b) found in the cave. Scale bar: $5 \mathrm{~cm}$

The hill of Kastritsa is constituted of the Ionian zone deposits as follows (Fig. 2):

- In the west of the hill there is a small sized outcrop of Vigla formation (js in the geological map) which consists of thin bedded limestones with abundant flint layers and nodules. The presence of Calpionellidae and radiolarians assigned the formation to a late Jurassic- early Senonian age. The same formation outcrops in the north, south and west of the cave, all in close proximity.

- A formation of turbiditic intercalations of brecciated to microbrecciated and micritic limestones of Late Senonian age constitutes the main part of the Kastritsa hill (cs-7 in the geological map). Some flint intercalations are observed in this formation. Micropaleontological analysis of the brecciated and microbrecciated limestones reveal fragments of rudists and fragments of the neighbouring Gavrovo platform of variable size. In the matrix, benthic foraminifera (Orbitoididae, Siderolites) as well as planctonic foraminifera (Globotruncanidae, Heterohelicidae) and radiolarians constitute the characteristic microfauna. The Kastritsa cave is formed in this geological formation.

- The Paleocene - Eocene formation (e in the geological map) that overlies in stratigraphical continuity is composed of turbiditic intercalations of brecciated and microbrecciated with micritic limestones. Rare intercalations of flint layers and nodules are observed. Fragments of the Gavrovo platform as well as benthic foraminifera (Nummulitidae, Orthophragminidae, Alveolinidae) and planctonic foraminifera (Globigerinidae, Globorotaliidae) are encountered within the brecciated limestones. Micritic limestones contain mainly Globigerinidae, Globorotaliidae and radiolaria. A small outcrop of this formation is noted in the southeastern part of the hill, representing the eastern flank of the syncline. 


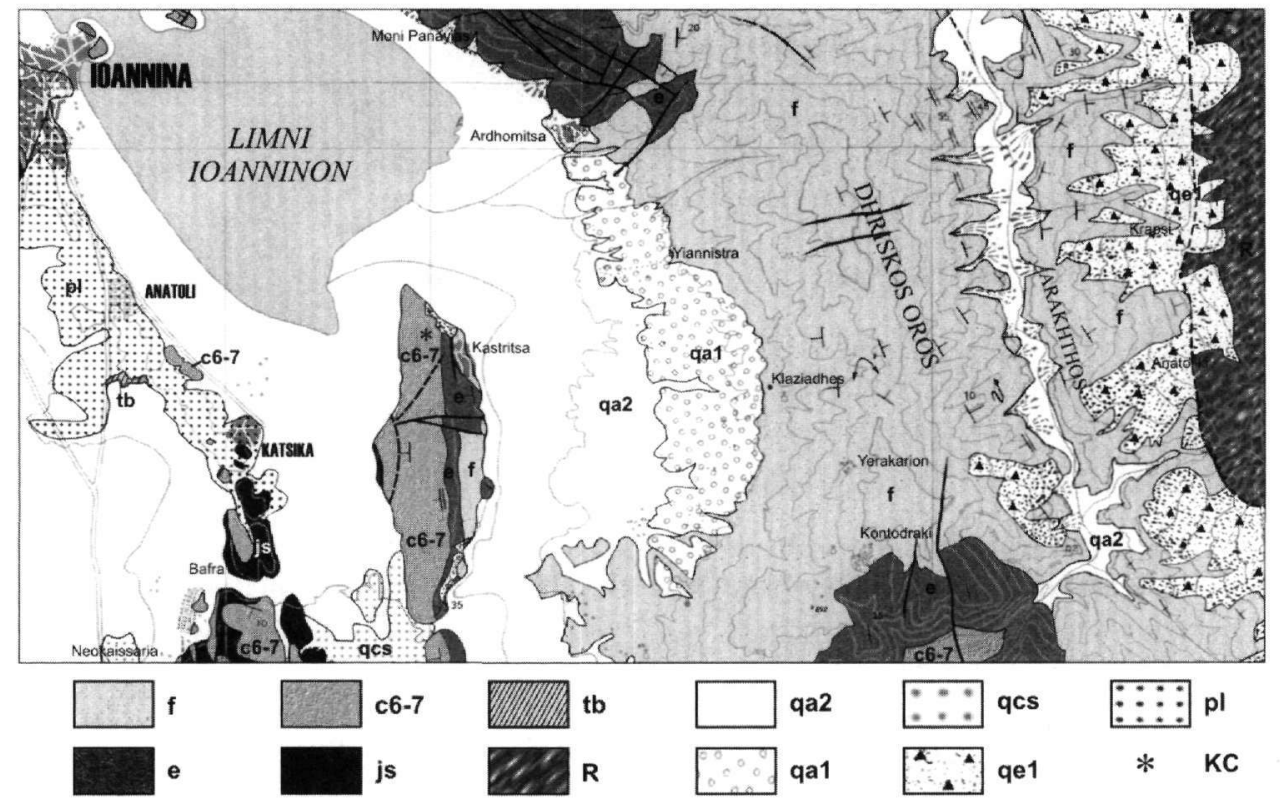

Figure 2 - Geological map of the studied area (after IGRS \& IFP 1966 simplified) showing the location of Kastritsa Cave. f: flysch, e: Paleocene-Eocene formation, c6-7: Late Senonian formation, js: Vigla formation, tb: Triassic breccia, R: Pindus Radiolarite formation, qa2: Recent alluvial deposits, qa1: ancient alluvial deposits, qcs: talus cone with siliceous elements, qe1: consolidated debris, pl: lacustrine Pliocene, KC: Kastritsa cave

- Clastic Flysch formation of Oligocene age is overlain in conformity (of in the geological map)

According to the above description, the most likely sources for chert collection are primarily the Vigla formation, and secondary the Senonian and Paleocene-Eocene formations. Other chert source could be found in the radiolarite formation of Pindus zone that outcrops further to the east.

\section{Micropaleontological and biostratigraphical study of the material}

For the purposes of this research thirteen archaeological samples were thin-sectioned. Some sections were entirely represented by silicicated sediment, while in other sections a part of the carbonate sediment that encountered the siliceous nodule or was interstratified with, was also noted (Fig. 5b). In some cases, carbonate remnants were observed in the siliceous nodule. The same microfossils were observed in the carbonate and the siliceous material. In most cases the observed microfossils were well preserved leading to a safe identification.

The results of the micropaleontological analysis have as follows:

1) Five samples contained microfossils such as Globigerinidae, Globorotaliidae, Rotaliidae, radiolarians and spines of echinoids (Figs 3,4). The provenance of the above samples is the Paleocene-Eocene geological formation of the Ionian zone. This formation outcrops in the immediate vicinity of the cave.

2) In one silex sample a fragment that might be attributed to Calpionellids was identified among abundant radiolarians (Fig. 5a). The provenance of this sample could be the Vigla formation.

3) In a third sample where limestone cortex is preserved around the chert nodule (Fig. 5b), abundant and well preserved radiolarians were identified in both the carbonate and silex material. 

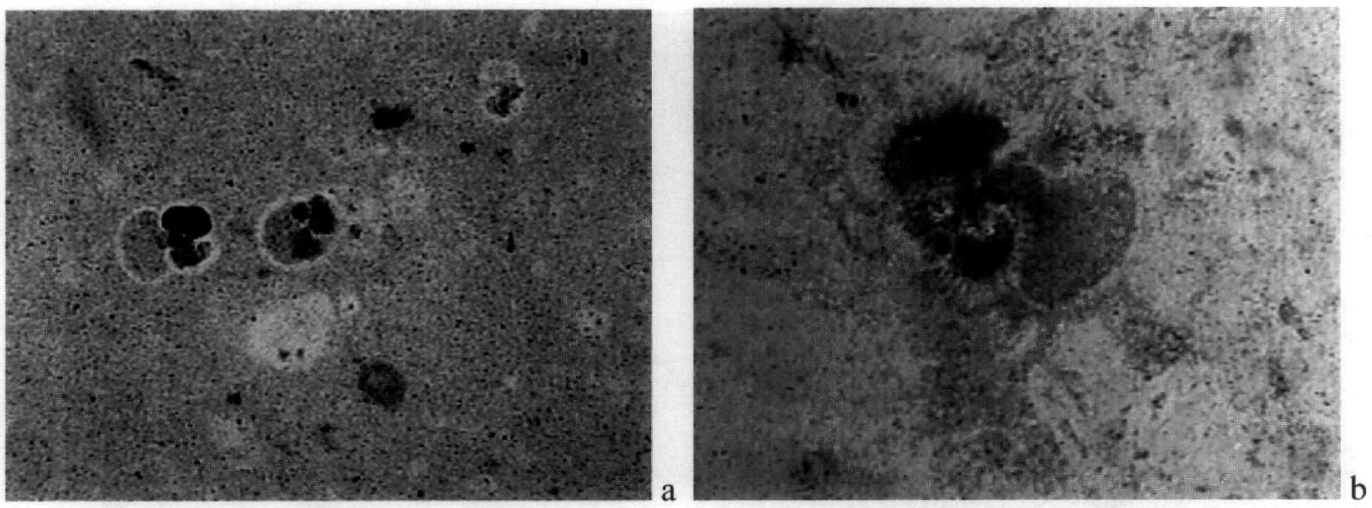

Figure 3 - a, b: Microphotographs of Globigerinids in flint material of paleolithic instruments. Provenance of raw material Paleocene-Eocene formation
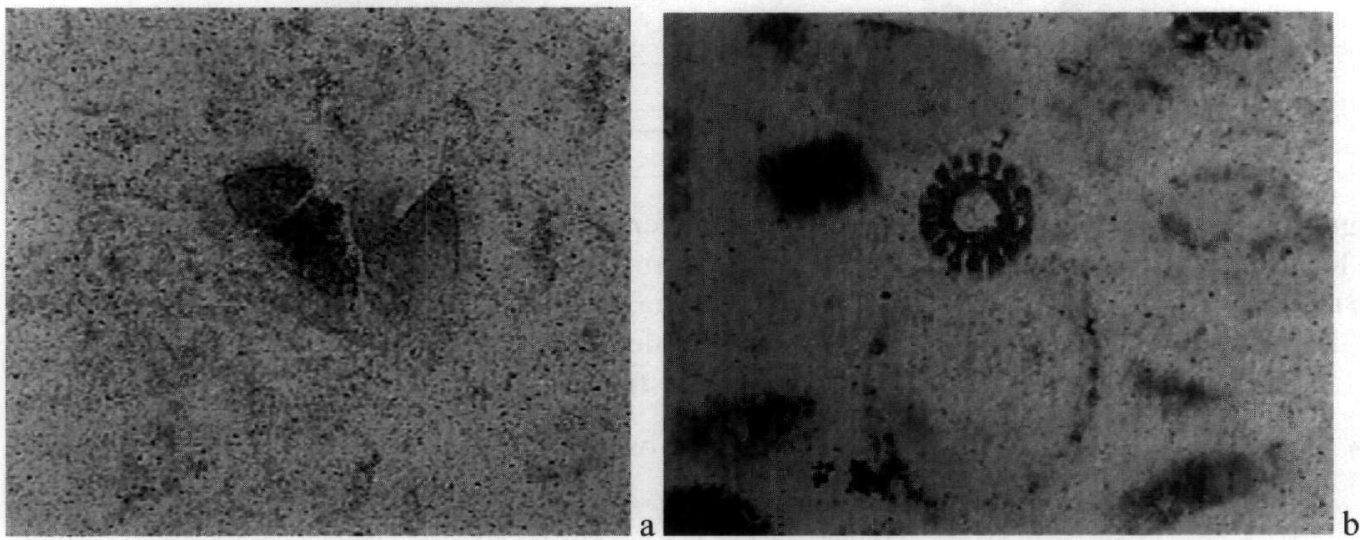

Figure 4 - Microphotographs of Globorotalia (a) and spine of echinoid (b) in flint material of paleolithic instruments. Provenance of raw material Paleocene-Eocene formation
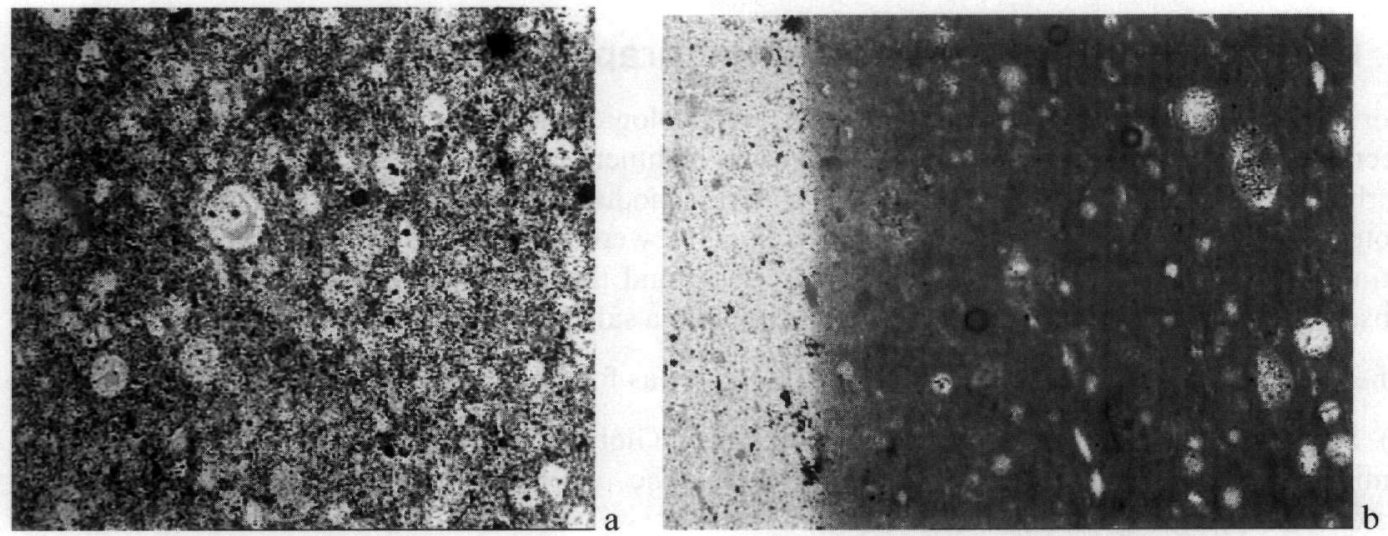

Figure 5 - a, b: Microphotographs of radiolarians in flint material of paleolithic artefacts. Possible provenance of raw material Vigla formation b: flint nodule with preserved carbonate cortex containing the same microfauna

The abundance of radiolarians in conjunction to the absence of other microfossil groups in this sample led to the conclusion that the Vigla formation could be the raw material source for the specific artefact. The formation of Radiolarites of the Pindus zone is located just $10 \mathrm{~km}$ east of 
Kastritsa and therefore it could also be a possible raw material source. However, access to this area would involve negotiation of mountainous blocks such as Driskos which reaches $1000 \mathrm{~m}$ in altitude, as well as the Arachthos valley (Fig. 2). In this light, we think that the Vigla formation is a better candidate of the provenance of the specific raw material, although the second option can not be ruled out entirely.

\section{Conclusions}

The present paper has demonstrated the valuable contribution of the micropaleontological/biostratigraphical analysis to raw material studies in archaeology. As has been discussed elsewhere (Elefanti and Zambetakis-Lekkas in prep.) the conclusions of this analysis will help us to build a better understanding of the way that Palaeolithic hunter-gatherers were organising their daily activities in the area during the last glaciation, an area of archaeological research still largely undeveloped. Drawing evidence from different lines of archaeological and geological data, we can argue that raw material procurement strategies at Kastritsa were locally organised.

The micropaleontological/ biostratigraphical method has shown that although its application in archaeological projects has not been fully embraced, it can deliver significant results with regard to the origin of raw materials. The high credibility, the simplicity and the low cost of the method, suggest that it ought to be one of the initial methods utilized in the archaeological research concerning sedimentary rocks. In addition, considering the tiny size of microfossils, a very small sized sample is sufficient in order to proceed to any biostratigraphical analysis. This may be of crucial importance for certain archaeological researches, where archaeological objects must not be destroyed.

\section{References}

Church, T., 1994. Lithic resource studies: A Sourcebook for Archaeologists. Lithic Technology Special. Publication 3. Tulsa, OK: University of Tulsa Press.

Elefanti, P., 2003. Hunter-gatherer specialised subsistence strategies in Greece during the Upper Palaeolithic from the perspective of lithic technology, Oxford: International Series of British Archaeological Reports (BAR 1130).

Elefanti, P., and Zabetakis-Lekkas, A., in prep. Raw material geological and biostratigraphic analysis from the Upper Palaeolithic Kastritsa cave ( $n-w$ Greece) and its contribution to regional mobility strategies.

Henderson, J., 2000. The science and archaeology of materials. An investigation of inorganic materials, London and New York: Routledge.

I.G.R.S. \& I.F.P., 1966. Etude geologique de l'Epire. (Grèce nord-occidentale), Editions Technip Paris. 306pp.

Zambetakis-Lekkas, A., Provia, C., Stamatakis, M.G., and Adamopoulou, V., 2001. The contribution of biostratigraphy to the identification of the origin of building stones used in the past. An example of the Delphi quarries, Proceedings of the 8th Euroseminar on Microscopy Applied to Buildings Materials September 4-7 2001, Athens Greece, 35-42pp. Ann. Géol. des Pays Hell. Edition spéciale, 35-42pp. 